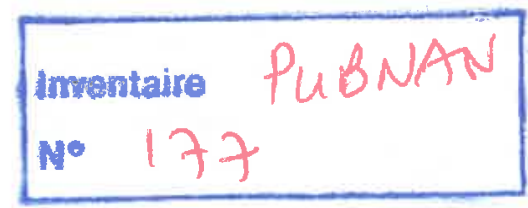

Reprinted from JOURNAL OF AGRICULTURAL AND FOOD CHEMISTRY, 1986, 34, 326.

Copyright (5) 1986 by the American Chemical Society and reprinted by permission of the copyright owner.

\title{
Nonstarchy Polysaccharides of Phaseolus vulgaris, Lens esculenta, and Cicer arietinum Seeds
}

\author{
Martine Champ, ${ }^{1}$ Jean-Marc Brillouet, ${ }^{*}$ and Xavier Rouau
}

\begin{abstract}
Nonstarchy polysaccharides of three legume seeds (kidney bean, lentil, chickpea) have been isolated and analyzed. Trichloroacetic acid soluble materials represent respectively $7.1,0.8$, and $2.1 \%$ of kidney bean, lentil, and chickpea whole dry seeds. Arabinose is the major sugar of the three extracts. Their arabinose:galactose ratios are respectively 1:0.35, 1:0.77, and 1:0.57. Cotyledon cell walls were defatted and then treated with pronase and $\alpha$-amylase. Dry matter ranged from $7.5 \%$ in lentil to $13.7 \%$ in chickpea. Cell walls from kidney bean, lentil, and chickpea contained respectively 67,73 , and $42 \%$ pectic polysaccharides associated with 16,12, and $10 \%$ cellulose. Arabinose was the major pectic sugar of the three walls. Hulls were mainly composed of cellulose (29-41\%) associated with hemicellulosic and pectic polymers. They had low lignin contents (1.2-1.7\%). Kidney bean hulls contained the greatest percentage of the (xylose + glucose) pair whereas chickpea exhibited the greatest amount of pectic polysaccharides.
\end{abstract}

\section{INTRODUCTION}

Legume seeds have been extensively studied by biochemists and nutritionists mainly for their proteins that constitute more than $30 \%$ of the seed and are better balanced in amino acids than most other plant proteins. Moreover, several studies suggest that they seem to decrease postprandial hyperglycemia (Jenkins et al., 1980a,b) and cholesterolemia (Mathur et al., 1968) and increase transit rate (Saraswathi and Shurpalekar, 1983) in humans.

However diarrhea has been observed in chicken fed raw and cooked kidney beans whereas chickpea and lentil did not induce such effects (Mansouri et al., 1983). Nonstarchy polysaccharides may be implicated in this disorder; therefore, the present study was undertaken to provide detailed information on these compounds.

\section{MATERIALS AND METHODS}

Plant Material. Seeds of kidney bean (Phaseolus vulgaris, cv. Michelet), chickpea (Cicer arietinum, cv. Aïn

Laboratoire de Biochimie et Technologie des Glucides, Institut National de la Recherche Agronomique, 44072 Nantes Cedex, France.

${ }^{1}$ Present address: Laboratoire de Technologie des Aliments des Animaux, 44072 Nantes Cedex, France.
Temouchent), and lentil (Lens esculenta, cv. Large Blonde du Chili) were provided by the National Agronomic Institute of El Harrach (Algeria). Seeds were hand dehulled and freed from germ. Cotyledons and hulls were ground in a cooled $\left(0^{\circ} \mathrm{C}\right)$ mill (lka M20) respectively for 3 and 4 $\mathrm{min}$ to pass a $0.5-\mathrm{mm}$ sieve.

Chemicals. $\alpha$-Amylase from Bacillus subtilis (EC 3.2.1.1, type II-A $1000 \mathrm{U} / \mathrm{mg}$ ) and pronase from Streptomyces griseus $(6 \mathrm{U} / \mathrm{mg})$ were respectively obtained from Sigma and Boehringer (Mannheim, Germany). All reagents were of analytical grade.

Preparation of Soluble Nonstarchy Polysaccharides. Whole seeds were grossly ground in a cooled $\left(0^{\circ} \mathrm{C}\right) \mathrm{IKA} \mathrm{M} 20 \mathrm{mill}(3 \mathrm{~min})$ and then in a cooled ball grinder (Dangoumeau) to pass through a $0.5-\mathrm{mm}$ sieve. A 100 -g portion of flour was treated with $500 \mathrm{~mL}$ of $10 \%$ $(\mathrm{w} / \mathrm{v})$ trichloroacetic acid (TCA) for $16 \mathrm{~h}$ at $4^{\circ} \mathrm{C}$ under continuous stirring and then centrifuged for $30 \mathrm{~min}$ at $10000 \mathrm{~g}\left(0^{\circ} \mathrm{C}\right)$. Extraction of soluble polysaccharides was performed with cold $10 \%$ trichloroacetic acid to prevent extensive solubilization of cytoplasmic proteins (Susheelamma and Rao, 1978). Cooling prevents any acid hydrolysis of labile $\alpha$-L-arabinofuranosidic linkages in the polysaccharides. The insoluble residue was retreated twice with TCA as described above. The supernatant liquids 
Table I. Composition of TCA-Soluble Polysaccharides

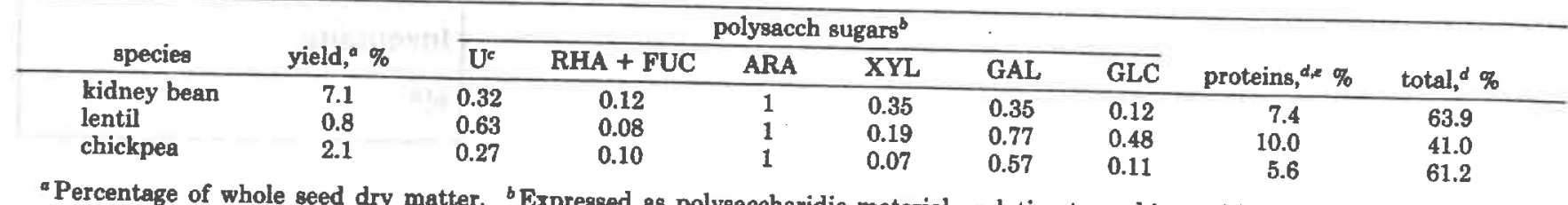

colorimetrically. "Percent on dry weight basis. $N \times 5.8$.

combined, filtered on a sintered-glass crucible (porosity 4 ), and adjusted to a final $60 \%$ concentration of acetone. After $16 \mathrm{~h}$ at $4{ }^{\circ} \mathrm{C}$, the white precipitate was collected by filtration, thoroughly washed with acetone, and dried with ether.

Preparation of Cotyledon Cell Walls. A 1-g portion of native cotyledon flour was exhaustively washed with a chloroform/methanol mixture $(2: 1)$ at $40^{\circ} \mathrm{C}$ in a sintered-glass crucible (porosity 3). Defatted seed meal was deproteinized by pronase $\left(0.4 \mathrm{~g} / \mathrm{L}\right.$ in $0.1 \mathrm{M} \mathrm{PO}_{4}$ buffer, $\mathrm{pH}$ $7.5,0.02 \% \mathrm{NaN}_{3}$ ) at $20^{\circ} \mathrm{C}$ under continuous stirring. After 16-h hydrolysis, the residue was washed with water, retreated with pronase $(0.2 \mathrm{~g} / \mathrm{L})$ for $4 \mathrm{~h}$, and then copiously washed with water. The white deproteinized residue was suspended under violent stirring for $10 \mathrm{~min}$ in $20 \mathrm{~mL}$ of boiling water to allow starch gelatinization. Then, the temperature of the viscous suspension was adjusted to 50 ${ }^{\circ} \mathrm{C}$ and $5 \mathrm{~mL}$ of $\alpha$-amylase solution $(0.3 \mathrm{~g} / \mathrm{L}$ in $0.1 \mathrm{M}$ acetate buffer, $\mathrm{pH}$ 5.6) was added under continuous stirring. After 2 -h hydrolysis, the residue was washed with distilled water and retreated under the same conditions. The defatted, deproteinized, and destarched residue (purified cell walls) was thoroughly washed with water and dried with ethanol, acetone, and ether.

Purity of cell wall preparations was checked under a light microscope using Fast green staining for proteins and $I_{2}$ /IK for starch (Brillouet and Carrê, 1983).

Analytical Methods. Moisture determination were carried out by heating samples at $130^{\circ} \mathrm{C}$ for $2 \mathrm{~h}$; all yields and compositions are given on a moisture-free basis.

Nitrogen was determined by the micro-Kjeldahl procedure and converted into protein by a conversion factor of 5.8. Lignin was analyzed by a slightly modified acetyl bromide procedure (Morrison, 1972; Monties and Rambourg, 1978): alkali-labile phenolic acids bound to the lignin core were eliminated by treating cell walls with 1 $\mathrm{M} \mathrm{NaOH}$ for $24 \mathrm{~h}$ at $20^{\circ} \mathrm{C}$; then lignin measurement were carried out in the usual way with a kraft lignin as a standard (Westvaco).

Cell wall polysaccharides from cotyledons and hulls was hydrolyzed according to Saeman et al. (1954) $\left(72 \% \mathrm{H}_{2} \mathrm{SO}_{4}\right.$ at $20^{\circ} \mathrm{C}$ for $2 \mathrm{~h}$ for cotyledon cell walls, $4 \mathrm{~h}$ for hull cell walls; then dilution to $1 \mathrm{M}, 100^{\circ} \mathrm{C}, 2.5 \mathrm{~h}$ ) or by $2 \mathrm{~N}$ trifluoroacetic acid (TFA) at $120^{\circ} \mathrm{C}$ for $1.25 \mathrm{~h}$ (Albersheim et al., 1967) whereas soluble polysaccharidic fractions were hydrolyzed by TFA.

Chromatographic Methods. TCA-soluble nonstarchy polysaccharides were submitted to gel permeation chromatography on a $(740 \times 26 \mathrm{~mm}$ i.d.) glass column filled with Sepharose CL-4B (Pharmacia, Upsala, Sweden) and equilibrated with $0.3 \% \mathrm{NaCl}\left(20^{\circ} \mathrm{C}\right)$ to prevent any ionic interactions with residual charges of the support. Fractions (7 mL) were collected and analyzed automatically for their neutral sugar and galacturonic acid contents. Neutral sugars were determined by orcinol method (Tollier and Robin, 1979) using mixtures of arabinose and galactose as standards in the following ara/gal ratios: kidney bean, 1:0.42; lentil, 1:0.85; chickpea, 1:0.59. Uronic acids were analyzed by the $m$-phenylphenol method (Thibault, 1979) using galacturonic acid as a standard. Responses were corrected for interferences.

Individual neutral monosaccharides were converted to their alditol acetates (Sawardeker et al., 1965) and analyzed by gas-liquid chromatography on a glass column (180 $\times$ $0.2 \mathrm{~cm}$ ) packed with $3 \%$ SP-2340 coated on $100-120$ mesh Supelcoport (Supelco, Bellefonte, PA) at $225^{\circ} \mathrm{C}\left(\mathrm{N}_{2}, 20\right.$ $\mathrm{mL} / \mathrm{min}$ ) using inositol as internal standard (Brillouet et
al., 1982).

\section{RESULTS AND DISCUSSION}

TCA-Soluble Polysaccharides. Yields of TCA-soluble material were respectively $7.1,0.8$, and $2.1 \%$ of kidney bean, lentil, and chickpea whole dry seeds. Among these three legume seeds, the kidney bean gave a far higher yield of soluble material than the others. This was reflected by the high viscosity of the bean TCA extract as opposed to lentil and chickpea ones. The strong viscosity of water or TCA extracts from flours of Phaseolus genus seeds has been documented by Susheelamma and Rao (1978) on Phaseolus mungo (black gram) and Sathe and Salunkhe (1981) on Great Northern Bean (P. vulgaris L.). They obtained, using a similar procedure, a polysaccharide constituting respectively 4.5 and $2.5 \%$ of the flour and having a very high viscosity around $\mathrm{pH} 6.7$ that decreased with increasing temperature.

TCA extracts from kidney bean, lentil, and chickpea contained respectively $40.8,28.2$, and $49.1 \%$ of neutral polysaccharides and $9.6,6.9$, and $8.3 \%$ of acidic ones, as determined by orcinol and $m$-phenylphenol colorimetric analyses. Neutral moieties as obtained by GC analysis of alditol acetates were $46.9,24.1$, and $47.3 \%$, respectively. The minor discrepancies between GC and colorimetric analysis may be due to imperfect orcinol standardization with arabinose and galactose. Although these are the major sugars in the extracts, other monosaccharides may be present and give different responses to orcinol. Respectively 57,31 , and $56 \%$ of extracts were determined as carbohydrates, the remaining part being partly made of soluble proteins. Neutral/acidic sugar molar ratios were $6.0,4.1$, and 6.8 . The polysaccharidic composition of the three extracts is indicated in Table I.

Arabinose was the major sugar present in the three seeds, but the kidney bean fraction had a higher proportion of xylose than lentil and chickpea. Molar proportions of xylose, galactose and uronic acid were almost the same in the kidney bean extract. In the lentil seed, arabinose:galactose ratio was higher than those of chickpea and kidney bean. Its uronic acid/rhamnose ( + fucose) molar ratio is 2.8 times higher than in bean and chickpea. Proportion of glucose in lentil seed is high and can be attributed to a glucan of starch origin. In the chickpea extract, galactose is, proportionally, the second highest sugar, arabinose being
the major one.

Gel permeation chromatograms are shown in Figure 1. For the three seeds, neutral:acid sugar ratios increased when the size of separated molecules decreased, but the evolution of this ratio is different from one seed to another. 
Table II. Composition of Cotyledon Cell Wall Polysaccharides

\begin{tabular}{|c|c|c|c|c|c|c|c|c|}
\hline \multirow[b]{2}{*}{ species } & \multirow[b]{2}{*}{ yield, ${ }^{\circ} \%$} & \multicolumn{6}{|c|}{ polysacch sugars $^{b}$} & \multirow[b]{2}{*}{ total, $\%$} \\
\hline & & $\mathrm{U}^{e}$ & RHA + FUC & ARA & XYL & GAL & $\overline{\text { GLC }}$ & \\
\hline \multirow[t]{2}{*}{ kidney bean } & 10.7 & 0.28 & 0.08 & 1 & 0.21 & 0.09 & 0.37 & 63.2 \\
\hline & & 0.25 & 0.08 & 1 & 0.24 & 0.11 & 0.73 & 86.2 \\
\hline \multirow[t]{2}{*}{ lentil } & 7.5 & 0.32 & 0.07 & 1 & 0.12 & 0.13 & 1.11 & 69.9 \\
\hline & & 0.26 & 0.03 & 1 & 0.14 & 0.11 & 1.25 & 87.3 \\
\hline \multirow{2}{*}{ chickpea } & 13.7 & 0.28 & 0.03 & 1 & 0.08 & 0.06 & 0.15 & 37.3 \\
\hline & & 0.21 & 0.03 & 1 & 0.11 & 0.08 & 0.42 & 56.7 \\
\hline
\end{tabular}

a Percentage of cotyledon dry matter. 'bee Table I. 'See Table I. 'First-line TFA hydrolysis. Second-line Saeman hydrolysis. 'Percent on dry weight basis.

Kidney bean extract was eluted in three fractions, the first two fractions were well separated, first was eluted at void volume and the second between void and total volume. Their respective neutral:acid sugar ratios were 2.3, 9.3, and 17.4. All the fractions were heterogeneous in composition, the first one containing $78 \%$ of total uronic acids and $43 \%$ of total neutral sugars. Qualitative analysis of the three fractions shows that the largest molecules eluted in the first fraction were the richest in rhamnose and the intermediate fraction was the richest in glucose and in xylose whereas arabinose predominated in the total volume range.

The chromatogram obtained from lentil extract presented three well-separated fractions; the intermediate peak was dissymmetrical in its lower part. The first part was mainly arabinose and uronic acid. Minor sugars were xylose, galactose, glucose, and rhamnose. In the second part, composition was not very different but uronic acids and rhamnose proportions decreased. The minor peak eluted in total volume was enriched in galactose and glucose.

With chickpea extract, most molecules were eluted in total volume and no intermediate peak could be observed on the chromatogram. Apart from the decreasing proportion of uronic acids from the void to the total volume, the main evolution of the composition is an increasing proportion of arabinose and a decreasing proportion of glucose.

Cotyledon Cell Wall Polysaccharides. Purity of lentil and chickpea cotyledon cell walls seemed to be good as shown by the absence of both Fast green and iodine stainings under light microscope. Walls from kidney bean still contained traces of starch as shown by light violet staining under iodine/potassium iodide.

The yields and composition of purified cell walls are indicated in Table II. The two Viciae species under study, chickpea and lentil, exhibited very different proportions of cell wall in their kernels. Lentil had wall content similar to broad bean (Vicia faba) and pea (Pisum sativum) (Brillouet and Carré, 1983).

The proportion of kidney bean cell wall content is probably slightly overestimated due to traces of starch, but Brillouet and Carre (1983) have also found high proportion of cell wall (9.3\%) in another legume seed, the soya bean (Glycineae).

These cell walls were composed mainly of nonstarchy polysaccharides that accounted respectively for $84.6,82.6$, and $52.2 \%$ of the lentil, kidney bean, and chickpea cotyledon cell walls. Noncarbohydrate matter was assumed to be pronase-resistant wall protein, phenolics, and minerals as suggested by Brillouet and Carrē (1983).

Cotyledon cell walls from the three seeds were thought to be of the primary cell wall like type because of their polysaccharidic constitutions that were characteristic of dicotyledonous primary cell walls. They are mainly composed of arabinose (mean of $26.8 \%$ ) and galacturonic acid (mean of $9.2 \%$ ) as the major noncellulosic pectic sugars.

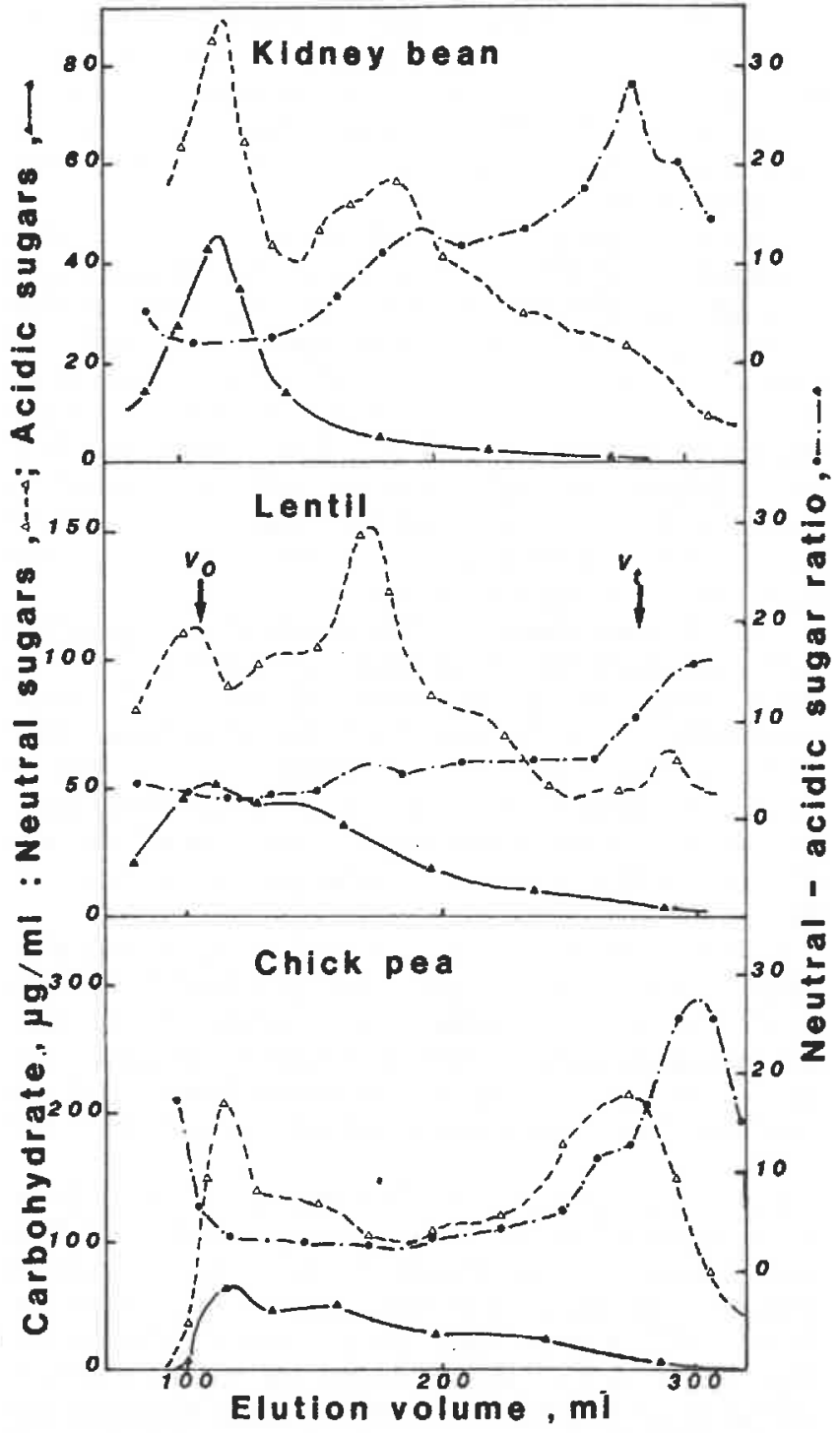

Figure 1. Gel permeation chromatograms of $10 \%$ TCA-soluble nonstarchy polysaccharides from kidney bean, lentil, and chickpea on Sepharose CL-4B $(740 \times 26 \mathrm{~mm})$. After sample loading (respectively 35,90 , and $104 \mathrm{mg}$ of sample in $7.5 \mathrm{~mL}$ of $0.3 \% \mathrm{NaCl}$ ), the column was eluted with $0.3 \% \mathrm{NaCl}$.

However, walls from kidney been contain a higher quantity of xylose $(6.9 \%)$ than those from lentil $(3.4 \%)$ and chickpea $(2.4 \%)$, which could not be accounted from residual hull fragments since hand dehulling was conducted very carefully.

The arabinose:galactose ratios of the bean (1:0.10), lentil (1:0.12), and chickpea (1:0.07) cell walls were very similar to those of pea (1:0.10) or broad bean (1:0.09) as observed by Brillouet and Carrë (1983).

The glucose contents obtained after TFA and Saeman hydrolyses are given in Table II. TFA is known to hy- 
Table III. Composition of Legume Seed Hulls

\begin{tabular}{|c|c|c|c|c|c|c|c|c|c|}
\hline \multirow[b]{2}{*}{ species } & \multirow{2}{*}{ yield, ${ }^{a} \%$} & \multicolumn{6}{|c|}{ polysacch sugars, ${ }^{b}$ anhydropolymeric \% } & \multirow[b]{2}{*}{ lignin, \% } & \multirow[b]{2}{*}{ total ${ }_{1}^{f s} \%$} \\
\hline & & $\mathrm{U}^{e}$ & $\mathrm{RHA}+\mathrm{FUC}^{d}$ & ARA & XYL & GAL & $\mathrm{GLC}^{\mathrm{d}, \mathrm{e}}$ & & \\
\hline $\begin{array}{l}\text { kidney bean } \\
\text { lentil } \\
\text { chickpea }\end{array}$ & $\begin{array}{l}6.2 \\
4.5 \\
4.4\end{array}$ & $\begin{array}{l}16.6 \\
10.6 \\
24.8\end{array}$ & $\begin{array}{l}(0.8) \\
(0.6) \\
(2.5)\end{array}$ & $\begin{array}{r}10.5 \\
3.9 \\
5.7\end{array}$ & $\begin{array}{r}10.8 \\
9.5 \\
2.6\end{array}$ & $\begin{array}{l}1.6 \\
1.6 \\
4.0\end{array}$ & $\begin{array}{l}44.1(3.0) \\
37.4(4.1) \\
32.8(3.8)\end{array}$ & $\begin{array}{l}1.2 \\
1.7 \\
1.4\end{array}$ & $\begin{array}{l}85.5 \\
54.7 \\
73.8\end{array}$ \\
\hline
\end{tabular}

a Percentage of hull in the seed. ${ }^{b}$ Mean from Saeman and TFA hydrolysis values. "Uronic acids determined colorimetrically. ${ }^{d}$ (Rhamnose + fucose) and glucose from TFA hydrolysis in parentheses. ${ }^{e}$ Glucose from Saeman hydrolysis. 'Percent on dry weight basis. 8 Glucose from Saeman hydrolysis and rhamnose from TFA hydrolysis taken into account. Total does not include unindentified minor sugars.

drolyze a small percentage of the cellulose, whereas Saeman hydrolysis liberates the bulk of the cellulosic glucose (Selvendran and Du Pont, 1980). Lentil and kidney bean gave rather large amounts of glucose on TFA treatment (29.9 and $12.6 \%$, respectively, of the total dry matter). Even if some of the TFA-liberated glucose originated from amorphous cellulose, most of it must be of noncellulosic $\beta$-glucan origin.

Assuming that a rather good estimation of cellulose is provided by the difference between glucose obtained from Saeman and TFA hydrolysis, it must be pointed out that the cell walls of kidney bean, lentil, and chickpea contained respectively $15.7,11.9$, and $10.3 \%$ of cellulose, which corresponds respectively to $1.7,0.9$, and $1.4 \%$ of cotyledon dry matter of seed. Our cellulose figures for kidney bean and chickpea were higher than the cellulose content obtained on faba bean, pea, and soya bean $(0.8,0.6$, and 0.8 part per 100) (Brillouet and Carré, 1983), but the content measured for lentil was similar.

Hull Polysaccharides. The chemical composition of hulls from the three legume seeds is indicated in Table III. Hulls were mainly composed of nonstarchy polysaccharides: $84.3,53.0$, and $72.4 \%$ for kidney bean, lentil, and chickpea, respectively. Cellulose represented respectively about 41,33 , and $29 \%$ of kidney bean, lentil, and chickpea hulls. Lignin was present in small amounts. Reichert (1981) observed a similar proportion (1.4\%) in pea hulls.

Uronic acids, which are supposed to be of both glucuronic and galacturonic type, constituted from $11 \%$ (lentil) to $25 \%$ (chickpea) of hulls. Noncellulosic neutral sugars are mainly arabinose and xylose. Molar ratios of arabinose, xylose, and uronic acids are for kidney bean, lentil, and chickpea hulls, respectively, 1.0:1.0:1.2, 1.0:2.4:2.1, and 1.0:0.5:3.4.

Relative proportions of cellulose and noncellulosic polysaccharides found in those three legume differed from data obtained for pea (Reichert, 1981). In this case, the author found, by the Van Soest method (Van Soest and Wine, 1967), a much higher proportion of cellulose than that found in the present study; on the contrary, he probably underestimated hemicellulosic fractions and pectic substances.

\section{CONCLUSION}

The main difference between the nonstarchy polysaccharides of the three legume seeds kidney bean, lentil, and chickpea is the proportion of $10 \%$ trichloroacetic- soluble material: respectively, $7.1,0.8$, and $2.1 \%$. The extract obtained from kidney bean is highly viscous and could be responsible for the diarrhea observed in chicken fed raw or cooked kidney bean.

Cell wall content of the kidney bean, lentil, and chickpea cotyledons is respectively $10.7,7.5$, and $13.7 \%$. Kidney bean cell walls have a high proportion of xylose and are the richest in cellulose (about 16\%).

Hulls represent about 5\% of the dry matter of the studied legume seeds. They are mainly composed of cellulose and have low lignin contents.

Registry No. Arabinose, 147-81-9; galactose, 59-23-4; cellulose, 9004-34-6; lignin, 9005-53-2; xylose, 58-86-6; glucose, 50-99-7; rhamnose, 3615-41-6; fucose, 2438-80-4.

\section{LITERATURE CITED}

Albersheim, P.; Nevins, D. J.; English, P. D.; Karr, A. A. Carbohydr. Res. 1967, 5, 340.

Brillouet, J. M.; Joseleau, J. P.; Utille, J. P.; Lelievre, D. J. Agric. Food Chem. 1982, 30, 488.

Brillouet, J. M.; Carrẻ, B. Phytochemistry 1983, 22, 841.

Jenkins, D. J. A.; Wolever, T. M. S.; Taylor, R. H.; Ghafari, H.; Jenkins, A. L.; Barker H.; Jenkins, M. J. A. Br. Med. J. 1980a, 5 July, 14.

Jenkins, D. J. A.; Wolever, T. M. S.; Taylor, R. H.; Barker, H. M.; Fielden, H. Br. Med. J. 1980b, 30 Aug, 578.

Mansouri, M.; Champ, M.; Delort-Laval, J. “Abstracts of Papers”, 3rd Meeting "Sciences des Aliments" of the French Nutrition Association (A.F.N.), Dijon, France, Dec 1983; Association Francaise de Nutrition: Jouy en Josas, France.

Mathur, K. S.; Khan, M. A.; Sharma, R. D. Br. Med. J. 1968, 6 Jan, 30.

Monties, B.; Rambourg, J. C. Ann. Technol. Agric. 1978, 27, 629.

Morrison, I. M. A. J. Sci. Food Agric. 1972, 23, 455.

Reichert, R. D. Cereal Chem. 1981, 58, 266.

Saeman, J. F.; Moore, W. E.; Mitchell, R. L.; Millett, M. A. Tappi $1954,37,336$.

Saraswathi, G.; Shurpalekar, K. S. Nutr. Rep. Int. 1983, 27, 1179.

Sathe, S. K.; Salunkhe, D. K. J. Food Sci. 1981, 46, 1276.

Sawardeker, J. S.; Sloneker, J. H.; Jeanes, A. Anal. Chem. 1965, $37,1602$.

Selvendran, R. R.; DuPont, M. S. Cereal Chem. 1980, 57, 278.

Susheelamma, N. S.; Rao, M. V. L. J. Agric. Food Chem. 1978, $26,1434$.

Thibault, J. F. Lebensm.-Wiss. Technol. 1979, 12, 247.

Tollier, M. T.; Robin, J. P. Ann. Technol. Agric. 1979, 28, 1.

Van Soest, P. J.; Wine, R. H. J. Assoc. Off. Anal. Chem. 1967, 50,50 .

Received for review May 23, 1985. Revised manuscript received October 7, 1985. Accepted October 23, 1985. 